\title{
Air-Drag Coefficient of Polyester Textured Yarns
}

\author{
SINTANI Ryuji* and OKAJIMA Atsushi** \\ *Industrial Research Institute of Ishikawa, Ro-1 Tomizu-machi, Kanazawa 920-0223, Japan \\ **Faculty of Engineering, Kanazawa University, 2-40-20 Kodatsuno, Kanazawa 920-8667, Japan
}

Received 22 August 2001; accepted for publication 7 May 2002

\begin{abstract}
The correspondence to consumer needs and the development of high value added products are required for the textile manufactures. The textile manufacture is obliged to shift to a large variety and small quantity of production. The improvement in efficiency of warp preparation and a quick determination of weaving conditions (air pressure and injection timing) is important to the air jet loom (AJL).

In order to obtain basic data for determining quickly the weaving conditions in AJL of the profile reed with sub-nozzles, the air-drag coefficient of eight kinds of polyester textured multi-filament yarn was measured, and the factors which affect the air-drag coefficient of yarn were investigated. The following conclusions were obtained as a result.

(1) The air-drag of polyester textured yarns which are 16.5 tex and 33.9 tex with 96 filaments became the largest.

(2) Measuring the diameter of polyester textured yarn used in the experiment, the diameter changes with the static loads and approaches to about 1.8 times as long as the equivalent diameter calculated from yarn count.

(3) The air-drag coefficient of polyester textured yarns used in the experiment is explained as a function of a Reynolds number.
\end{abstract}

Key Words: air-drag coefficient, polyester textured yarn, weft insertion, air jet loom

\section{ポリエステル加工糸の空気抗力係数}

\author{
新谷隆二* 岡島 厚**
}

\section{1. 緒 論}

織物製造業では消費者ニーズへの対応, 高付加価值製品 の開発が必要となっており,多品種少量生産への移行が余 儀なくされている. 織物製造業におけるエアジェットルー ム（AJL）を使用した多品種少量生産では, 品種変更に伴 う段取り換えを迅速に行うことが必要であり,たて糸準備 の効率化と製織条件 (空気圧力と空気噴射タイミング) の 決定が重要な課題として挙げられる.ここで製織条件につ いて注目すると, 製織条件の決定は実際に試織を行い，よ こ系の飛走状態を確認しながら行っているため, 未だ経験 と勘によるところが大きい. 特に製織現場では, よこ系飛
走不良で織機が停止するのを防ぐため, 空気圧力を高めに 設定する傾向がある.

AJL は, 空気と糸との摩擦により糸を搬送し，よこ入れ を行う織機である.ここで重要になるのは, 系の空気抗力 係数であり, AJL で製織される糸のほとんどが短繊維であ ることから, 系の空気力学的性質を表す短繊維の空気抗力 係数について, 樋口ら[1]が報告している. 化学繊維に関 しては, Gould ら[2]が, 一様流中で両端を固定した状態に おけるモノフィラメントの空気抗力係数を実験的に計測 し, 直径を代表長さとするレイノルズ数で整理できること を明らかにしている. 八田ら[3]は, スパンデックス糸の 空気抗力係数を明らかにしている.これらの研究から系の 空気抗力係数は, 系種によって異なることが明らかとなっ

* 連絡先 石川県工業試験場, 920-0223 金沢市戸水町口 1 番地, FAX: 076-267-8090,

** 金沢大学工学部, 920-8667 金沢市小立野 2-40-20, TEL. 076-234-4744 
ている.また,いずれも吸い込み風洞を用いた実験であり, マルチフィラメントについては, ほとんど報告されていな いのが現状である.

そこで本研究では, 現在主流となっている変形おさ補助 ノズル方式の AJL における製織条件の決定を迅速に行う ための基礎データを得ることを目的として, マルチフィラ メント糸であるポリエステル仮撚加工糸 8 種類の空気抗 力係数を測定し, 系の空気抗力係数に影響する要因につい て検討したので報告する．

\section{2. 記 号}

本報で用いた主な記号を以下に示す.

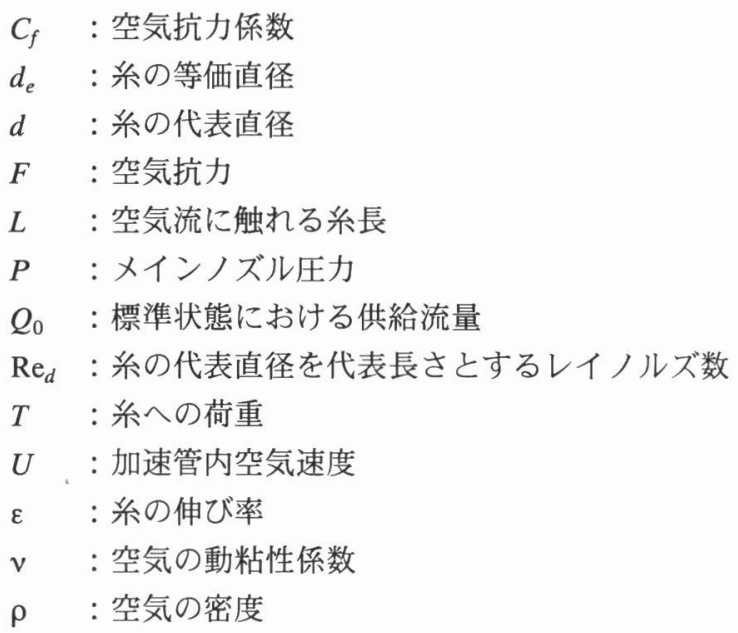

\section{3. 実験装置および実験方法}

\section{1 実験装置}

図 1 にポリエステル加工系の空気抗力を求めるために 用いた実験装置の概略を示す. 従来の研究では, 吸い込み 風洞を用いて実験しているが, 本研究においては, 特別な 実験装置を使わず製織現場で簡便に実験できるように, 実 際の AJL で使用されている加速管長さ $200 \mathrm{~mm}$, 出口内径 $3.9 \mathrm{~mm}$ のメインノズルを用いた. 空気抗力の測定には, 3 点式の張力計 (IRO 製 Yarn Tension Meter 最大荷重 200 cN）を用いた. また, 図 1 に示すように, メインノズル 入口部での空気圧力測定には, 半導体型圧力変換器（豊田 工機製 PMS5-10H)，また，供給流量の測定には，質量流 量計（CKD 製）を用いた。

\section{2 実験方法}

\section{(1) 空気抗力}

空気抗力 $F$ の測定は, 図 1 に示すように, 供試系の左 端を固定した片端支持の状態で行った.このときの糸長は メインノズル加速管内に系先端が存在するように, 把持点 から $350 \mathrm{~mm}$ の長さとした. また, メインノズル圧力 $P$ を $300 \mathrm{kPa}$ まで変化させ, サンプリング周波数 $1 \mathrm{~Hz}$ で 150 秒 間空気抗力と圧力および供給流量の測定を行った

マルチフィラメント糸は, フィラメント 1 本 1 本が絡み 合った複雑な形状をしているが, 本報告では, 円柱断面と 仮定し, 空気流と平行に置かれた円柱断面の空気抗力 $F$ は次式で与えられるものとした。

$$
F=\frac{1}{2} C_{f} \rho U^{2} \pi d L
$$

式(1)から空気抗力係数 $C_{f}$ は次式となる.

$$
C_{f}=\frac{2 F}{\rho U^{2} \pi d L}
$$

ここで, $U$ は加速管内の空気速度, $d$ は系の代表直径, $L$ は空気と触れる糸の長さである.

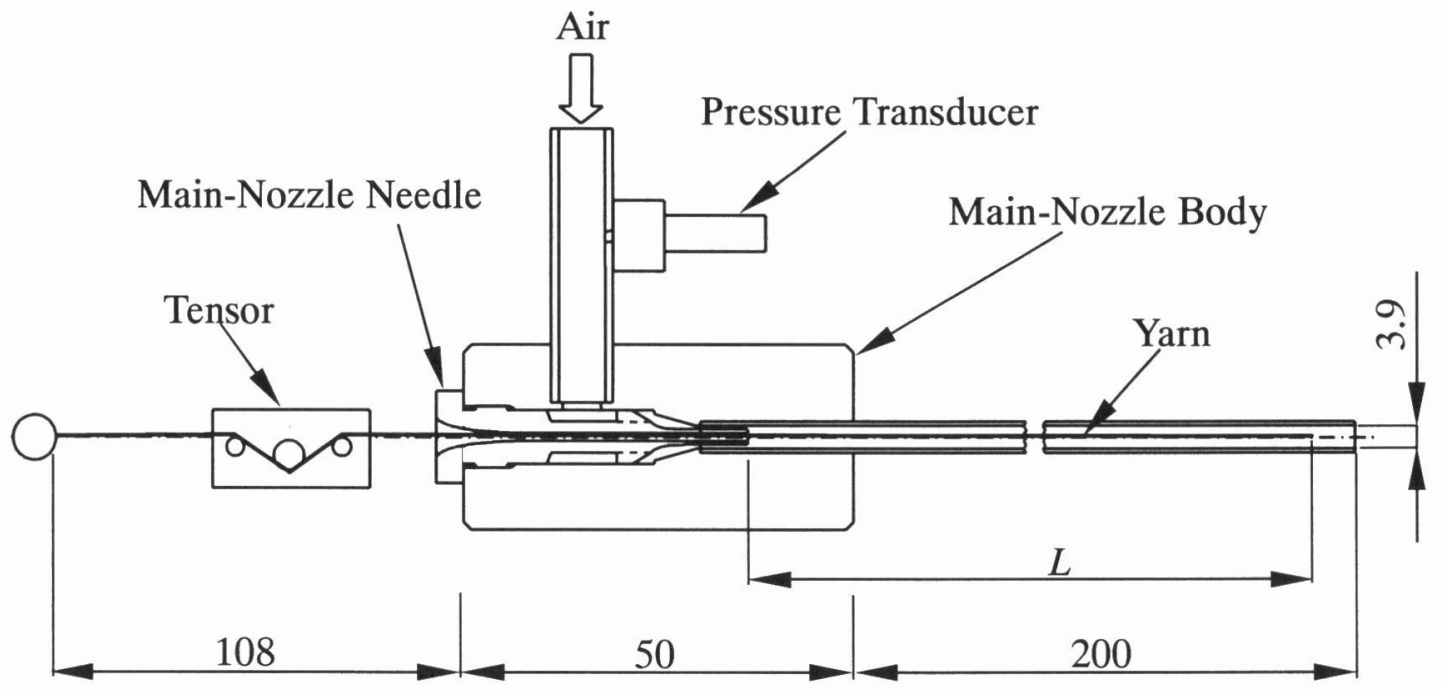

Fig.1 Schematic diagram of experimental equipment 


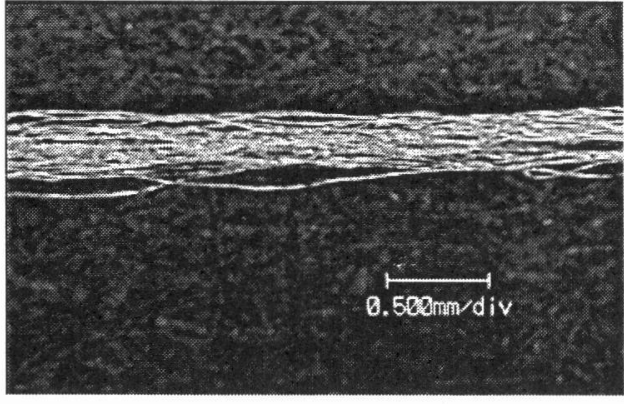

(a) 8.7 tex $/ 48 \mathrm{f}$

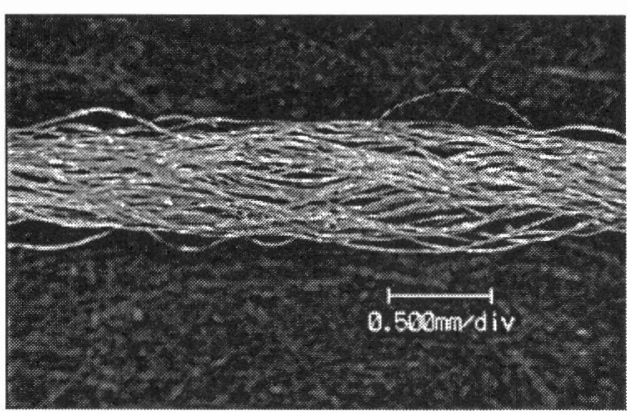

(c) $21.7 \mathrm{tex} / 72 \mathrm{f}$

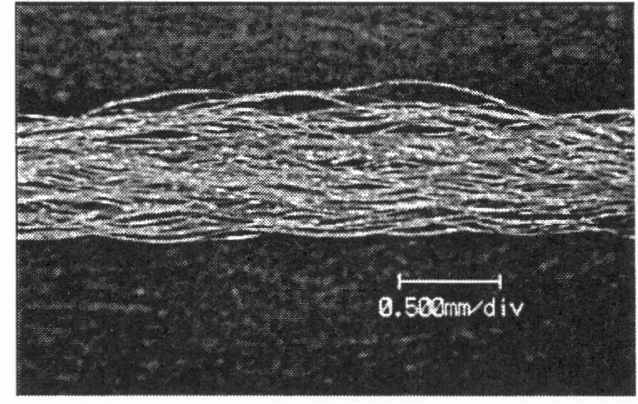

(b) 16.5 tex $/ 96 \mathrm{f}$

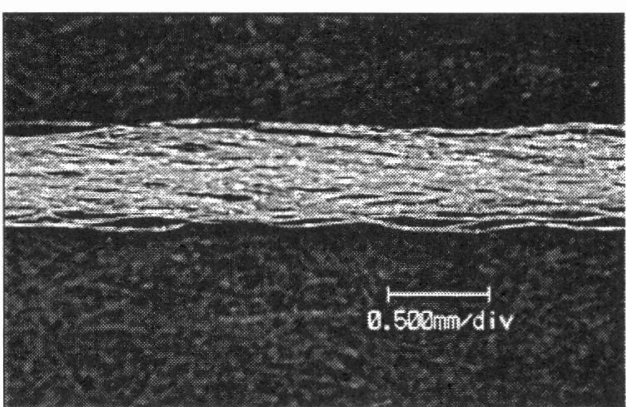

(d) 33.9 tex $/ 96 \mathrm{f}$

Fig.2 Over view of four test yarns

ポリエステル加工糸は, レギュラー系と比較して低荷重 域（後述のように $0.2 \mathrm{~N}$ 以下）での伸びが大きく、このと きの直径変化も大きいために、より有用な空気抗力係数を 算出するには、糸の伸びと直径変化を考慮する必要がある.

そこで式(2)において, 厳密には加速管内の空気速度, 糸に掛かる張力は, 場所によって異なり, 系の代表直径お よび伸び率も系の張力によって異なることになるが, 簡単 化のため, 空気速度については, 場所によって変化しない ものと仮定し, 系の代表直径および伸び率については, 静 的な特性の適用を試みた。

\section{（2）強伸度試験}

空気と触れる糸長 $L$ に, 系の静的な特性としての空気抗 力に対する伸びを考虑するため, インストロン製の万能材 料試験機（4301 型）を用いて, 供試系の強伸度試験を行 った．JIS の試験方法によれば，初荷重としてかさ高加工 糸の場合, $8.82 \mathrm{mN} \times$ (表示テックス) を付加する必要が あるが，本実験においては，初期の伸び率が重要と考え， 初荷重 $0 \mathrm{~N}$ として実験を行った。

\section{（3）代表直径}

マルチフィラメント糸で, 系を円柱と仮定した場合の直 径には, 系の纎度と比重量から求められる等価直径 $d_{e}$ を 用いることが多い。加工糸の場合, レギュラー系と比較し て糸の直径変化が大きいため, 等価直径を用いることは適 当でないと考えられる. そこで, 系の代表直径 $d$ の測定に
は, 非接触外径測定器 (ZIMMER 製 PORTABLE DIAMETER MONITER 460D/2 測定範囲 $0 \sim 2 \mathrm{~mm}$ )を用い た. 供試系 $300 \mathrm{~mm}$ の片端をU ゲージ式荷重変換器 (ミネ ベア製 UT-100g）に固定し，他端の自由端を引張した。 非接触外径測定器は, 固定端から $150 \mathrm{~mm}$ の位置に設置し た.

\section{3 供試糸}

実験には, 繊度とフィラメント数が異なる 8 種類のポリ エステル仮撚加工糸を用いた. 図 2 に 8 種類のうち 4 種類 の供試系外観を示す. 図に示すように, 供試系はフィラメ ント 1 本 1 本が複雑に絡み合い, 弾力性に富んだ構造であ

Table 1 Test yarns

\begin{tabular}{c|c|c|c}
\hline \hline No. & $\begin{array}{c}\text { Yarn } \\
\text { Count } \\
{[\text { tex] }}\end{array}$ & $\begin{array}{c}\text { Number of } \\
\text { Filaments }\end{array}$ & $\begin{array}{c}\text { Equivalent } \\
\text { Diameter } \\
{[\mu \mathrm{m}]}\end{array}$ \\
\hline 1 & 8.7 & 48 & 89.5 \\
\hline 2 & 8.1 & 72 & 86.2 \\
\hline 3 & 16.5 & 48 & 123.2 \\
\hline 4 & 16.5 & 96 & 123.2 \\
\hline 5 & 21.7 & 48 & 141.3 \\
\hline 6 & 21.7 & 72 & 141.3 \\
\hline 7 & 33.2 & 72 & 175.0 \\
\hline 8 & 33.9 & 96 & 176.8 \\
\hline
\end{tabular}


ることがわかる. 表 1 に, 供試糸の緎度とフィラメント数 を, 等価直径 $d_{e}$ の値とともに示す.

\section{4. 実験結果および考察}

\section{1 空気抗力}

図 3 は, 実験により得られた空気抗力を示す。横軸は, 標準状態（0 ${ }^{\circ} \mathrm{C}, 101.3 \mathrm{kPa}$ ）に換算した供給流量 $Q_{0}$ であ る.図 3 からわかるように, 約 $1.3 \times 10^{-3} \mathrm{~m}^{3} / \mathrm{s}$ の供給流量ま での空気抗力 $F$ は系種によらずほぼ同じ值である.

この流量範囲では, 加速管内に置かれた糸が管壁との接 触等により糸種による変化が現れなかったと考えられる.

また, それ以後の空気抗力は, 系種によりその傾向は異 なるが, 供給流量にほぼ比例して増加している. フィラメ ント数 96 の 16.5 tex と 33.9 tex の糸の空気抗力は, 他の系 の空気効力より大きい. 8.1 tex / $72 \mathrm{f}$ と $16.5 \mathrm{tex} / 48 \mathrm{f}$ の糸 の空気抗力は, 一番小さい. その他の系の空気抗力はこの 中間にあり, 実験した糸では 3 グループに分かれるようで ある.

空気抗力は, AJLでよこ入れを行う場合に糸を加速する カとなる. このことから, 16.5 tex / $96 \mathrm{f}$ と 33.9 tex / $96 \mathrm{f}$ の系は, 実験に用いた他の糸よりメインノズルの噴流によ る加速力が一番大きく, 8.1 tex / $72 \mathrm{f}$ の糸の場合, メイン ノズル噴流による加速力が実験した糸の中で一番小さく なると考えられる.

\section{2 供試系の強伸度}

実験に用いたポリエステル加工糸はかさ高性を有し, 図 2 に示したようにフィラメントが直線状ではなく曲線状 となっているため, 通常のポリエステル系より小さな荷重 での伸びが大きい. そこで, 前節で得られた空気抗力の範

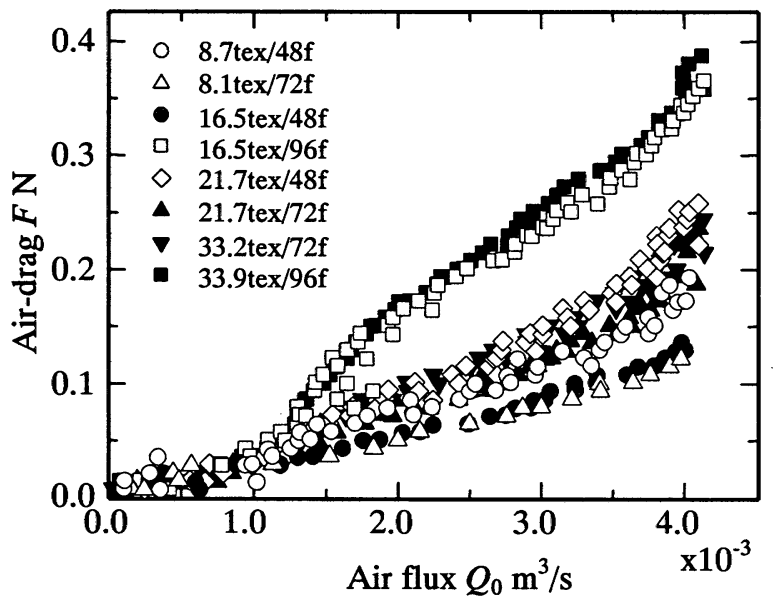

Fig.3 Air-drag of polyester textured yarn
囲における強伸度試験の結果を図 4 に示す. 縦軸は荷重 $T$, 横軸は伸び率 $\varepsilon$ である. AJL におけるよこ入れ中の糸に 作用する張力は，それ程大きくはなく，経験上 $0.2 \mathrm{~N}$ 以下 であることが知られている．それゆえ AJL のよこ入れを 考える場合 $0.2 \mathrm{~N}$ 以下での強伸度が重要であり, 図 4 から 糸種によって, $0.2 \mathrm{~N}$ 以下での伸び率が大きく異なること がわかる.

AJL のよこ入れに重要と考えられる荷重範囲よりも大 きいが, 試験した荷重範囲での強伸度曲線を, 最小二乗法 を用いて次式で近似した.

$$
T=c_{1} \varepsilon^{c_{2}}
$$

ここで, $c_{1}$ と $c_{2}$ は定数である.

16.5 tex / $96 \mathrm{f}$ の糸について, 求めた近似曲線を図 5 に示 す. 得られた曲線の相関係数は 0.98 である. 同様にして, 他の糸について求めた近似曲線の定数を表 2 に示す.いず

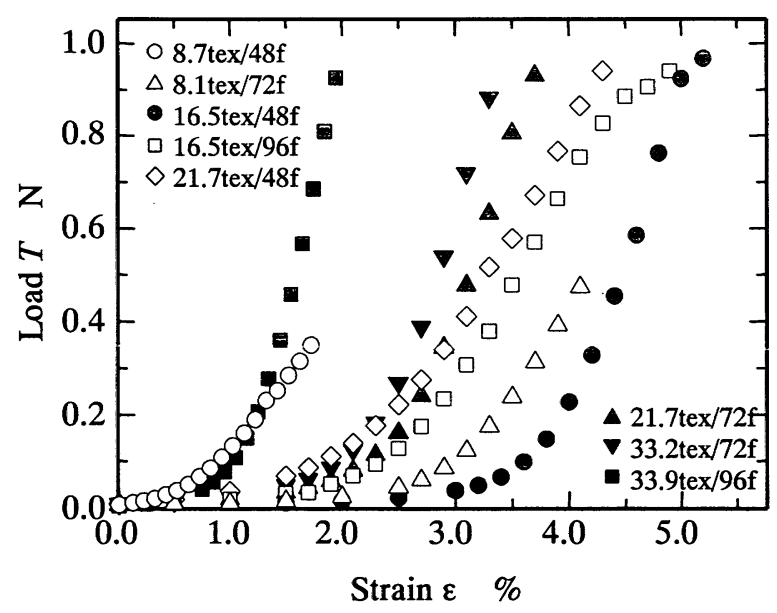

Fig.4 Tenacity of polyester textured yarn

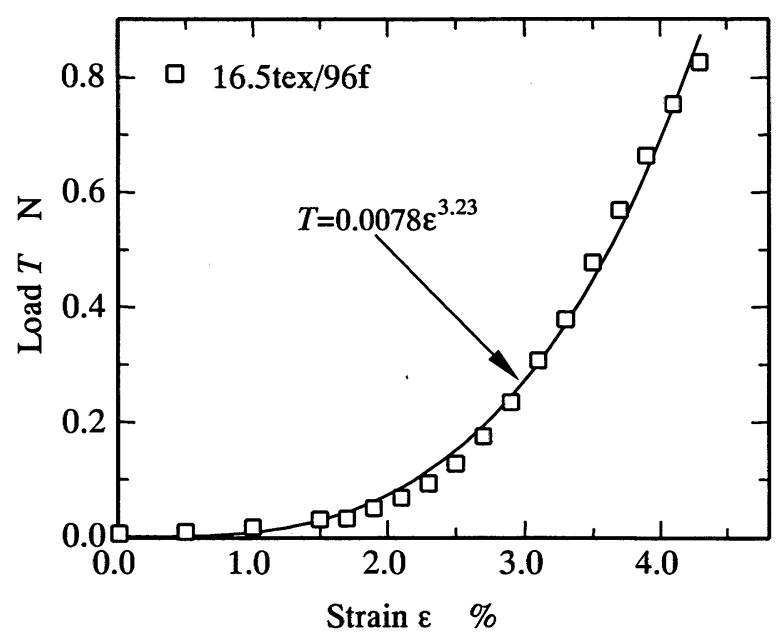

Fig.5 Curve fitting for tenacity of polyester textured yarn of 16.5 tex/96f 
Table 2 Results of Curve fitting for tenacity

\begin{tabular}{c|c|c|c}
\hline \hline No. & Yarn kind & $c_{1}[\mathrm{~N}]$ & $c_{2}$ \\
\hline 1 & 8.7 tex $/ 48 \mathrm{f}$ & 0.1275 & 1.93 \\
\hline 2 & 8.1 tex $/ 72 \mathrm{f}$ & 0.0005 & 4.73 \\
\hline 3 & 16.5 tex $/ 48 \mathrm{f}$ & 0.0001 & 5.46 \\
\hline 4 & 16.5 tex $/ 96 \mathrm{f}$ & 0.0078 & 3.23 \\
\hline 5 & 21.7 tex $/ 48 \mathrm{f}$ & 0.0195 & 2.69 \\
\hline 6 & 21.7 tex $/ 72 \mathrm{f}$ & 0.0039 & 4.21 \\
\hline 7 & 33.2 tex $/ 72 \mathrm{f}$ & 0.0048 & 4.44 \\
\hline 8 & $33.9 \operatorname{tex} / 96 \mathrm{f}$ & 0.1039 & 3.32 \\
\hline
\end{tabular}

れの場合も得られた曲線と実験データとの相関係数は 0.96〜0.98であった.

\section{3 供試糸の糸直径}

前節においても説明したが, ポリエステル加工糸はかさ 高性を有している. 図 6 は代表直径 $d$ について, 16.5 tex / $96 \mathrm{f}$ の糸の荷重に対する変化を示すが, 特に荷重 $0.2 \mathrm{~N}$ 以 下における系の代表直径変化が大きいことがわかる. 図中 の破線は, 表 1 に示した等価直径 $d_{e}$ である. 16.5 tex / $96 \mathrm{f}$

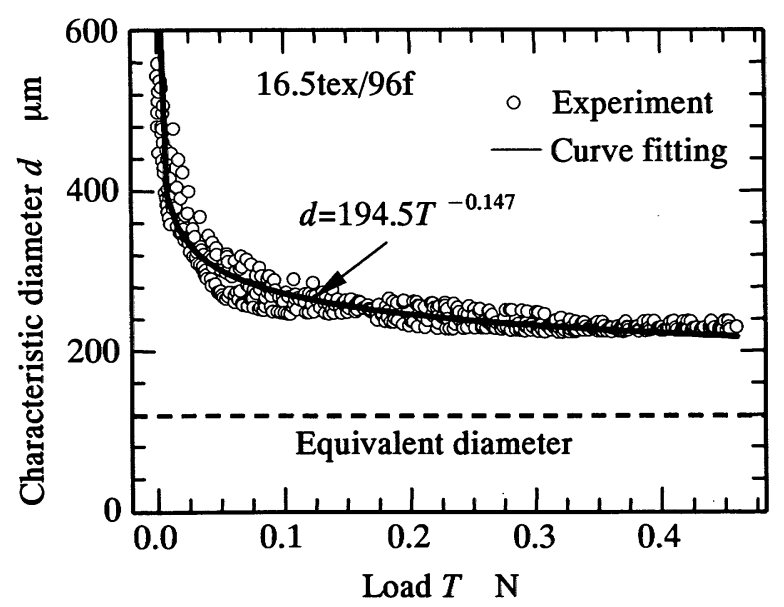

Fig.6 Characteristic diameter of polyester textured yarn of 16.5 tex/96f

Table 3 Results of Curve fitting for characteristic diameter

\begin{tabular}{c|c|c|c}
\hline \hline No. & Yarn kind & $c_{3}$ & $c_{4}$ \\
\hline 1 & 8.7 tex/48f & 133.0 & -0.101 \\
\hline 2 & 8.1 tex/72f & 121.6 & -0.163 \\
\hline 3 & 16.5 tex/48f & 198.6 & -0.146 \\
\hline 4 & 16.5 tex/96f & 194.5 & -0.147 \\
\hline 5 & 21.7 tex/48f & 257.0 & -0.103 \\
\hline 6 & 21.7 tex/72f & 250.3 & -0.113 \\
\hline 7 & 33.2 tex/72f & 332.4 & -0.092 \\
\hline 8 & 33.9 tex/96f & 321.2 & -0.106 \\
\hline
\end{tabular}

の糸の場合, 荷重 $0.2 \mathrm{~N}$ 以上でほぼ一定の代表直径になる ことがわかる. しかしながら，一定となる代表直径は，等 価直径よりは大きく，等価直径の約 1.8 倍である.

代表直径と荷重の関係を, 最小二乗法を用いて次式で近 似した。

$$
d=c_{3} T^{c_{4}}
$$

ここで, $c_{3}$ と $c_{4}$ は定数である. また, 式(4)で使用する荷 重 $T$ の単位は $\mathrm{N}$, 計算される代表直径の単位は $\mu \mathrm{m}$ である.

16.5tex/96f の糸について, 得られた曲線の相関係数は 0.96 である. 同様にして, 他の糸について求めた近似曲線 の定数を表 3 に示す.いずれの場合も得られた曲線と実験 データとの相関係数は 0.89〜0.96であった.

また, 式(4)では, $T \rightarrow 0$ のとき $d \rightarrow \infty$ となるため, $d>3 c_{3}$ となる場合, $d=3 c_{3}$ とした.

\section{4 空気抗力係数}

系の空気抗力係数を求めるにあたり, 前節で求めた糸の 静的な特性の適用を試みた. すなわち, 空気速度 $U$ に対 して得られた空気抗力を $T_{1}$ として, 式(3)を用いて式(5)で 計算した伸び率 $\varepsilon$ を空気と触れる系の長さ $L$ に考慮し, 式(4)を用いて式(6)で計算した值を代表直径 $d$ とした.

$$
\begin{aligned}
& \varepsilon=\frac{1}{T_{1}} \int_{0}^{T_{1}}\left(\frac{T}{c_{1}}\right)^{\frac{1}{c_{2}}} d T \\
& d=\frac{1}{T_{1}} \int_{0}^{T_{1}} c_{3} T^{c_{4}} d T \\
& \operatorname{Re}_{d}=\frac{U d}{v}
\end{aligned}
$$

式(5)と(6)で得られた值を式(2)に代入して計算した空気 抗力係数 $C_{f}$ を式(7)の糸の代表直径を代表長さとするレイ ノルズ数 $\mathrm{Re}_{d}$ で整理した結果を図 7 に示す. 図中に示す実

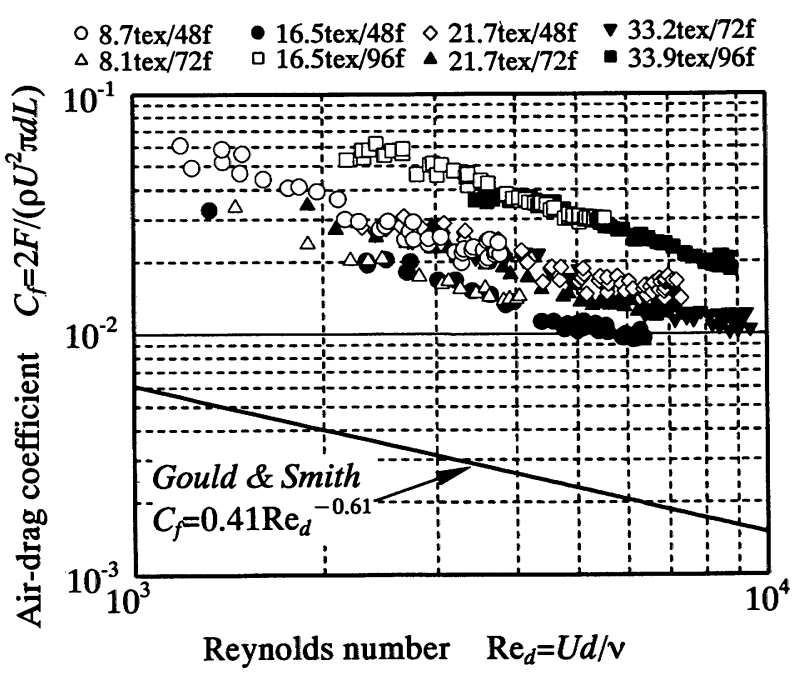

Fig.7 Air-drag coefficient of polyester textured yarn 
線は, Gould ら[2]の両端支持の条件下でのモノフィラメン トによる実験結果である. 図から空気抗力係数のレイノル ズ数に対する変化は, 纎度には依存せず, 図 3 の空気抗力 と同じように 3 つのグループに分かれている.特にフィラ メント数 96 本の糸 16.5 tex と 33.9 tex が, 実験した中では 一番大きな空気抗力係数となった. また, 得られた空気抗 力係数は, Gould らの結果よりもかなり大きな值を示して いる. この理由としては, ポリエステル加工糸は糸の構造 から空気との接触面積が多いことと, 実験条件が片端支持 であるので, 主として自由端の振動や曲率を持つことによ り, 空気抗力係数が大きくなったものと考えられる.

また, これまでの糸の空気抗力係数を求める実験は, 空 気流の安定性から吸い込み流を用いており,レイノルズ数 としては 400 以下であり, 1000 以上の大きな值での実験 が行われていない. しかし, 本実験では, エアジェットル 一ムに用いられるメインノズルを用いた噴き出し流であ り, 乱流中での実験であるにも関わらず, レイノルズ数の 増加による空気抗力係数の変化に関しては, Gould ら[2] の結果と同じ傾向がある.

このことから, 吸い込み流を用いた実験では, 空気抗力 係数は 400 以上のレイノルズ数でほぼ一定になると考え られていたが, 噴き出し流を用いることにより, 1000 か ら 10000 までの大きなレイノルズ数においても, 空気抗力 係数をレイノルズ数の関数として扱うことができると考 えられる.

Gould ら[2]や岩木ら[4]によれば, 系の空気抗力係数 $C_{f}$ は式(7)で与えられるレイノルズ数の関数として次式で表 されている.

$$
C_{f}=K \operatorname{Re}_{d}{ }^{n}
$$

表 4 には実験値から最小二乗近似により得られた式(8) の $K$ と $n$ の值を示す. Gould ら[2]によれば, 式(8)におけ る比例定数 $K$ は系のしまり具合等を表し, 指数 $n$ は表面 の滑らかさを表すと考えられている. 実験に用いたポリエ ステル加工糸の $n$ の值は, 繊度およびフィラメント数によ らずー0.76であることが明らかとなった. また, ポリエス テル加工系の代表直径は, 荷重 $0.2 \mathrm{~N}$ 以上のとき前述のよ うに纎度から求められる等価直径の約 1.8 倍であり, 荷重 の変化に対して直線的でなく, 指数関数的に減少している. この荷重に対する代表直径の変化が, 式(8)における比例 定数 $K$ の（系のしまり具合を表すと考えられる）値に大 きく影響し，3グループ分かれたものと考えられるが，そ の有意性については明確ではなく, 今後の検討課題である.

空気速度と系の直径が与えられた場合、レイノルズ数か ら空気抗力係数を求め, 空気抗力を計算した後, 得られた 空気抗力により系の伸びと系の直径を再計算し, 空気抗力 の值が収束するまでレイノルズ数の計算からを繰り返し 行うことにより, ポリエステル加工系の空気抗力を求める
Table 4 Results of Curve fitting for air-drag coefficient

\begin{tabular}{c|c|c|c}
\hline \hline No. & Yarn kind & $K$ & $n$ \\
\hline 1 & 8.7 tex/48f & 7.72 & \\
\hline 2 & 8.1 tex/72f & 5.04 & \\
\hline 3 & 16.5 tex/48f & 5.04 & \multirow{2}{*}{-0.76} \\
\hline 4 & 16.5 tex/96f & 14.8 & \\
\hline 5 & 21.7 tex/48f & 7.72 & \\
\hline 6 & 21.7 tex/72f & 7.72 & \\
\hline 7 & 33.2 tex/72f & 7.72 & \\
\hline 8 & 33.9 tex/96f & 14.8 & \\
\hline
\end{tabular}

ことが可能となる.

\section{5. 結論}

現在主流となっている変形おさ補助ノズル方式の AJL における製織条件の決定を迅速に行うための基礎デー夕 を得ることを目的として, マルチフィラメント糸であるポ リエステル加工系 8 種類の空気抗力係数を測定し, 系の空 気抗力係数に影響する要因につい検討した結果, 以下の結 論を得た.

(1) 実験したポリエステル加工糸の中では 96 フィラメン トの 16.5 tex と 33.9 tex の糸の空気抗力が一番大きくな った.

（2）実験に用いたポリエステル加工糸の代表直径を計測 した結果, 荷重によって代表直径は変化し, 荷重 $0.2 \mathrm{~N}$ 以上で繊度から求められる等価直径の約 1.8 倍に近づ $<$.

(3) 実験したポリエステル加工糸の空気抗力係数は, 糸の 代表直径を代表長さとするレイノルズ数の関数として 表され，このときの指数は, 繊度およびフィラメント 数によらずー0.76であることが明らかとなった.

(4) エアジェットルームのメインノズルを用いた噴き出 し流で実験を行った場合, 1000 から 10000 までのレイ ノルズ数においても, 空気抗力係数をレイノルズ数の 関数として取り扱うことができると考えられる.

\section{References}

[1] Higuchi K. and Kasahara Y.; J. Text. Mach. Soc. Japan, 15, 4, T335 (1962)

[2] J. Gould and F. S. Smith; J. Text. Inst., 71, 1, p.38 (1980)

[3] Hatta K., Kinari T., Shintaku S and Iwaki N.; J. Text. Mach. Soc. Japan, 50, 8, T216 (1997)

[4] Iwaki N., Kinari T. and Yamazaki H.; J. Text. Mach. Soc. Japan, 41, 10, T145 (1988) 